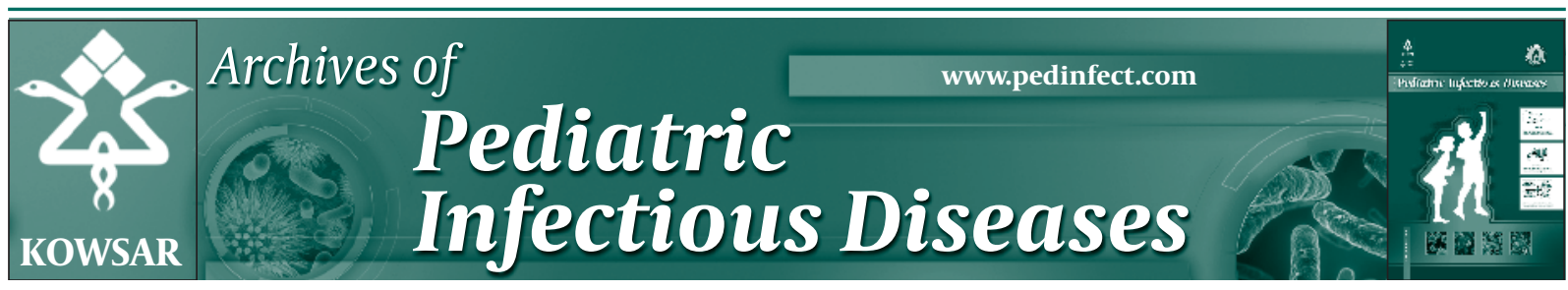

\title{
Comparison of High Loading Dose Versus Usual Dose of Rectal Acetami- nophen in the Treatment of Febrile Children
}

\author{
Houman Hashemian ${ }^{1}$, Mohammad Momtazbakhsh ${ }^{1}$, Zahra Atrkar Roshan \\ ${ }^{1}$ Department of Pediatrics, Faculty of Medicine, Guilan University of Medical Sciences, Rasht, IR Iran \\ ${ }^{*}$ Corresponding author: Houman Hashemian, 17th Shahrivar Hospital, Namjoo Street, Rasht, IR Iran. Tel: +98-1313220713, Fax: +98-1313226101, E-mail: hashem- \\ ian@gums.ac.ir.
}

\section{A B S T R A C T}

Background: The superiority of antipyretic efficacy of high dose rectal acetaminophen is not well established yet.

Objectives: The present study aimed to compare the antipyretic effectiveness of high loading dose ( $30 \mathrm{mg} / \mathrm{kg}$ ) and standard dose $(15 \mathrm{mg} / \mathrm{kg})$ of rectal acetaminophen in febrile children.

Patients and Methods: This triple blind randomized clinical trial was conducted on 76 patients aged 6 months to 6 years with rectal temperature of $>39^{\circ} \mathrm{C}$ who had been referred to 17th Shahrivar training hospital of Rasht, Guilan, Iran. The patients were assigned to one of two groups: First group ( $\mathrm{n}=37$ patients) received $15 \mathrm{mg} / \mathrm{kg}$ and the second group $(\mathrm{n}=39$ patients) received $30 \mathrm{mg} / \mathrm{kg}$ of acetaminophen rectally. The patient's rectal temperatures were measured before rectal acetaminophen administration and one and three hours post administration using Microlife rectal digital thermometer (Sweden) and were compared between the two groups. Results: One hour after rectal administration of acetaminophen the mean temperature changes in groups 1 and 2 were $0.97 \pm 0.59^{\circ} \mathrm{C}$ and $1.03 \pm 0.62^{\circ} \mathrm{C}$, respectively $(\mathrm{P}$ value $=0.663)$. A significant difference was seen in the mean temperature reduction between the two groups three hour after treatment $\left(1.22 \pm 0.72^{\circ} \mathrm{C}\right.$ vs. $1.57 \pm 0.65^{\circ} \mathrm{C}$, respectively; P value $\left.=0.028\right)$.

Conclusions: In febrile children, administration of $30 \mathrm{mg} / \mathrm{kg}$ of rectal acetaminophen as the loading dose may be more effective than the standard dose in reducing fever after 3 hours of medication.

Keywords: Acetaminophen; Child; Fever; Administration, Rectal

Copyright (@) 2013, Kowsar Corp.; Published by Kowsar Corp.

\footnotetext{
Article type: Research Article; Received: 19 Jan 2013, Revised: 29 Jan 2013, Accepted: 08 Apr 2013; DOI: 10.5812/pedinfect.10350

Implication for health policy/practice/research/medical education:

This research project was conducted from May 2009 to September 2010. The superiority of antipyretic efficacy of high dose rectal acetaminophen is not well established yet. On the basis of this study, we found that in febrile children, administration of $30 \mathrm{mg} / \mathrm{kg}$ of rectal acetaminophen may be more effective than the standard dose in reducing fever.

-Please cite this paper as:

Hashemian H, Momtazbakhsh M, Atrkar Roshan Z. Comparison of High Loading Dose Versus Usual Dose of Rectal Acetaminophen in the Treatment of Febrile Children. Arch Pediatr Infect Dis.2013;1(3): 126-30. DOI: 10.5812/pedinfect.10350
} 


\section{Background}

Fever is a common symptom in children and is believed to constitute 25 to $30 \%$ of medical and emergency room visits annually (1-3). It has been shown that a rectal temperature of less than $39^{\circ} \mathrm{C}$ does not need treatment (3-5). Moreover, world health organization emphasizes a fever of more than $39^{\circ} \mathrm{C}$ which produces complications for the patients, requires medical attention (6). It seems that judgment regarding the appropriate indication of fever reduction mostly relies on each patient's medical condition. In addition, choosing the appropriate fever treatment has been a challenging issue for a long time.

Antipyretic effects of acetaminophen are equal to that of aspirin. Besides, it does not have the side effects on the gastrointestinal system and platelets function. Considering these advantages made acetaminophen the preferred treatment of choice for the reduction of fever in children $(1,3,4)$.

Acetaminophen is generally administered in standard doses of 10-15 mg/kg either rectally or orally $(3,4)$. Though there is no general consensus on rectal acetaminophen as the preferred choice of route, in some situations where oral preparation cannot be administered such as in a vomiting child or due to the preferences of parents or the physician, administration of the drug via rectum is inevitable (7). Moreover, pharmacokinetic properties of single dose of oral acetaminophen are known $(8,9)$. Nevertheless, pharmacokinetics of its single rectal dose is not well established since its absorption is prolonged and depends on size of suppository, base composition, and rate of dissolutions (10). Although several investigations have been conducted on acetaminophen, it is not known whether different doses of rectal acetaminophen have similar effects in reducing fever. Previous literature revealed that serum concentration of 15-20 $\mu \mathrm{g} /$ $\mathrm{mL}$, which is considered as the therapeutic plasma level for antipyretic effect, could not be achieved by rectal dose of $10-15 \mathrm{mg} / \mathrm{kg}$ and a rectal dose of $30-45 \mathrm{mg} / \mathrm{kg}$ was needed (8-14). The maximum recommended daily dose of acetaminophen for children is $90 \mathrm{mg} / \mathrm{kg} /$ day (15). Toxic dose of acetaminophen is above $150 \mathrm{mg} / \mathrm{kg} /$ day or $12 \mathrm{~g} /$ day (16) and various studies about high loading dose acetaminophen use in children showed no obvious complications $(1,2,7,13)$.

\section{Objectives}

Since the antipyretic effect of acetaminophen is dosedependent and also the general consensus regarding the efficacy of high loading dose versus low dose rectal acetaminophen is lacking, this study was designed to compare the antipyretic effectiveness of the standard dose of $15 \mathrm{mg} / \mathrm{kg}$ rectal acetaminophen versus a $30 \mathrm{mg} /$ $\mathrm{kg}$ dose.

\section{Patients and Methods}

\subsection{Study Population}

This triple blind (patients, physician, and statistical analyzer) randomized clinical trial was conducted on 76 consecutive febrile children 6 months to 6 years old who had been referred to 17th Shahrivar hospital of rasht, Iran during May 2009 and September 2010 with rectal temperatures of $39^{\circ} \mathrm{C}$ to $40.5^{\circ} \mathrm{C}$ in the prior 24 hours and had no other signs in the physical exam. Patients with a history of diarrhea, malignancy, renal or liver failure, neurologic disorders, seizure, vasculitis, allergy to acetaminophen and who evacuated suppository during the first 30 minutes, or had received acetaminophen in the previous 4 hours were excluded from the study. We included patients with rectal temperatures of 39 ${ }^{\circ} \mathrm{C}$ and above. The study was approved by the research and ethics committee of Guilan university of medical sciences and written informed consent was obtained from the parents of all patients. The registration ID was IRCT138806182438N1.

The patients were randomly sorted into two groups. Thirty-seven patients took $15 \mathrm{mg} / \mathrm{kg}$ (low dose) and thirty-nine patients took $30 \mathrm{mg} / \mathrm{kg}$ (high dose) of rectal acetaminophen. Of these, 9 patients (24.3\%) from the first group (low-dose group) and 11 patients (28.2\%) from the second group (high-dose group) used oral antibiotics more than 8 hours prior to the study.

\subsection{Study Maneuver}

Patients were assigned to one of the two groups by using the random fixed block method. Four sample sealed packets (aabb, abab, abba, etc.) were designed. packets were chosen by-lot and patients were assigned to one of the two groups as the order of samples of each packet. Rectal acetaminophen was administered in lipophilic suppository form (Darou Pakhsh pharmaceutical manufacturing Co., Tehran, Iran). The $125 \mathrm{mg}$ and $325 \mathrm{mg}$ suppositories were cut in half or quarter longitudinally using a digital balance when necessitated.

A fixed trained nurse inserted the prepared suppository beyond the internal sphincter after lubrication. The patient's rectal temperatures were measured before rectal acetaminophen administration and one and three hours after, using Microlife rectal digital thermometer (Sweden) by a fixed pediatric resident who was blind to the patients' groups. The patients were placed in the prone position and the rectal thermometer was inserted into their rectums ( 2 to $2.5 \mathrm{~cm}$ ). After hearing the beep of the thermometer, patients' rectal temperatures were read and recorded and were then compared between the two groups. Patients stayed in the emergency room until 3 hours after acetaminophen consumption (end of the study) and no another intervention was made to control their fever. 


\subsection{Statistical Analysis}

The sample size was estimated on the basis of a pilot study on 20 consecutive febrile children between the ages of 6 months and 6 years who had visited the 17th Shahrivar hospital of Rasht, Iran. The patients were sorted into two equal groups (low dose and high dose rectal acetaminophen). Then, the sample size was calculated to be 40 for each group as shown below:

$(\mathrm{Z} 1-\alpha+\mathrm{Z} 1-\beta)^{2}\left(S 1^{2}+S 2^{2}\right) /\left(\mu_{1}-\mu_{2}\right)=(1.96+1.28)^{2}\left(0.3^{2}+\right.$ $\left.0.25^{2}\right) /(39.4-39.6)^{2}=40$

The analyzer was also blind. Statistical analysis was performed using the SPSS V.14 software. For each of the measured variables or indexes, descriptive values were expressed as the mean \pm SD. All data were initially analyzed using the Kolmogorov-Smirnov test to assess for normal- ity. Normally distributed numerical data were compared between groups using independent sample T and paired sample T tests. Discrete variables were analyzed using the chi-square analysis. All P-values were two-tailed and P < 0.05 was considered statistically significant.

\section{Results}

There were 31 girls (40.8\%) and 45 boys with mean age $25.3 \pm 17.7$ months (range: 6-72 months), mean body weight $12.6 \pm 3.7 \mathrm{~kg}$ (range: $6.3-21 \mathrm{~kg}$ ) and mean rectal temperature $39.72 \pm 0.40{ }^{\circ} \mathrm{C}$ (median: $39.5{ }^{\circ} \mathrm{C}$ and range: $39-40.5^{\circ} \mathrm{C}$ ). No significant difference was shown between these characters in the group of patients treated with high dose versus the group treated with low dose rectal acetaminophen (Table 1).

Table 1. Demographic Data of the Patients in the Two Groups Receiving Low Dose (15 mg/Kg) Versus High Dose (30 mg/Kg) of Rectal Acetaminophen

\begin{tabular}{llll}
\hline Data & Low Dose $(\mathbf{1 5} \mathbf{~ m g} / \mathbf{k g})$ & High Dose $(\mathbf{3 0 ~} \mathbf{m g} / \mathbf{k g})$ & P.value \\
\hline Gender & & & 0.672 \\
\hline Boys, No. (\%) & $21(56.8)$ & $24(61.5)$ & \\
\hline Girls, No. (\%) & $16(43.2)$ & $15(38.5)$ & 0.265 \\
Age (mo) & $23 \pm 17$ & $27.5 \pm 18.4$ & 0.397 \\
\hline Weight $(\mathbf{k g})$ & $12.2 \pm 3.8$ & $12.9 \pm 3.6$ & \\
\hline
\end{tabular}

Table 2. Data of the Patients at Baseline, One and Three Hours After Treatment, Receiving Low Dose (15 mg/kg) Versus High Dose (30 $\mathrm{mg} / \mathrm{kg}$ ) of Rectal Acetaminophen

\begin{tabular}{|c|c|c|c|}
\hline Data & Low Dose (15 mg/kg) & High Dose (30 mg/kg) & P.value \\
\hline Mean body temperature at the onset of study & $39.63 \pm 0.41^{\circ} \mathrm{C}$ & $39.80 \pm 0.37 \mathrm{C}^{\circ}$ & 0.063 \\
\hline Mean body temperature one hour after treatment & $38.66 \pm 0.64^{\circ} \mathrm{C}$ & $38.77 \pm 0.60^{\circ} \mathrm{C}$ & 0.443 \\
\hline $\begin{array}{l}\text { Mean of body temperature change one hour after treat- } \\
\text { ment }\end{array}$ & $-0.97 \pm 0.59^{\circ} \mathrm{C}$ & $-1.03^{\circ} \mathrm{C} \pm 0.62^{\circ} \mathrm{C}$ & 0.663 \\
\hline Mean of body temperature 3 hours after treatment & $38.41 \pm 0.69^{\circ} \mathrm{C}$ & $38.23 \pm 0.65^{\circ} \mathrm{C}$ & 0.238 \\
\hline $\begin{array}{l}\text { Mean of body temperature change during } 3 \text { hours after } \\
\text { treatment }\end{array}$ & $-1.22 \pm 0.72^{\circ} \mathrm{C}$ & $-1.57 \pm 0.65^{\circ} \mathrm{C}$ & 0.028 \\
\hline $\begin{array}{l}\text { At least } 2^{\circ} \mathrm{C} \text { decrease in body temperature one hour after } \\
\text { treatment, No. (\%) }\end{array}$ & & & 0.746 \\
\hline Yes & $3(8.1)$ & $4(10.3)$ & \\
\hline No & $34(91.9)$ & $35(89.7)$ & \\
\hline $\begin{array}{l}\text { At least } 2^{\circ} \mathrm{C} \text { decrease in body temperature } 3 \text { hours after } \\
\text { treatment, No. (\%) }\end{array}$ & & & 0.05 \\
\hline Yes & $6(16.2)$ & $14(35.9)$ & \\
\hline No & $31(83.8)$ & $25(64.1)$ & \\
\hline
\end{tabular}

All patients tolerated a high dose acetaminophen very well and no obvious complication occurred. Based on the parents' reports, nine (24.3\%) out of 37 children treated with low dose rectal acetaminophen and 11 (28.2\%) out of 39 children treated with high dose rectal acetaminophen had received oral antibiotic eight hours prior to the study.

\section{Discussion}

According to the findings of the present study, one and three hours after administration of both low dose and high dose rectal acetaminophen, the reduction of body temperatures of the patients were conspicuous. As shown in Table 2, our study showed that there was no sta- 
tistically significant difference between the mean body temperatures of these two groups at one and three hour intervals after treatment. Although, mean temperature reductions three hours after treatment were higher in patients administered a high dose rectal acetaminophen comparing to the patients treated with a low dose acetaminophen. After one hour, the frequency of patients who showed a $2{ }^{\circ} \mathrm{C}$ decrease in their body temperature was not different in the two groups but this difference was significant three hours after treatment ( $P$ value $=0.05$ ).

The results of the studies by Howell and Patel (17) and Beck et al. (18) showed plasma levels of acetaminophen were significantly higher in patients receiving a higher dose of acetaminophen with increased duration of drug action. Furthermore, the results of a study by Hahn et al. (11) on 23 children at ages 9 weeks to 11 years showed that the time needed to reach the therapeutic serum level was shorter when a higher dose of rectal acetaminophen was used. Results of these studies agree with our results regarding a higher efficacy of high dose rectal acetaminophen compared to the lower doses.

Tre luyer et al. (2) in a randomized clinical trial on 121 children aged 4 months to 9 years compared the antipyretic effects of two doses of $30 \mathrm{mg} / \mathrm{kg}$ and $15 \mathrm{mg} / \mathrm{kg}$ of oral acetaminophen. The duration required to obtain a temperature lower than $38.5^{\circ} \mathrm{C}$ was significantly shorter, the maximum temperature decrease was significantly higher, and duration of rectal temperature below $38.5^{\circ} \mathrm{C}$ was significantly longer in the $30-\mathrm{mg} / \mathrm{kg}$ than in the 15 $\mathrm{mg} / \mathrm{kg}$ group. These data suggest that acetaminophen treatment of fever may be more efficient with a higher loading dose and are compatible to our findings.

Golestan et al. (19) in a parallel group, randomized clinical trial on 60 febrile patients, 6 month to 6 years old, compared the antipyretic effects of two doses of $15 \mathrm{mg} / \mathrm{kg}$ and $10 \mathrm{mg} / \mathrm{kg}$ of oral acetaminophen. The rate of temperature reduction at the first and third hour post administration in group $1(15 \mathrm{mg} / \mathrm{kg})$ was significantly higher. The authors concluded acetaminophen with dose of $15 \mathrm{mg} / \mathrm{kg}$ is more effective in reducing fever.

It should be noted that absorption time of rectal preparation of acetaminophen is slower compared to the orally administered route. Rectal absorption of acetaminophen depends on the size, basic component and the solubility of the suppository, its location in the rectum and the ingredients within the rectum (10). It seems that slower absorption of rectal acetaminophen and inability to reach the therapeutic plasma level during the first hour after treatment with the two different doses can be a probable reason for the fact that during the first hour of rectal acetaminophen administration, there is no significant difference between low and high dose preparations. Besides, as the effects of acetaminophen begins to appear 0.5 to 1 hour after treatment and reaches the peak serum level during 1 to 3 hours (20), detection of the difference between high versus low doses 3 hours after administration in our study seems logical. However, the results of some studies in this regard were not consistent with ours. For example, Nabulsi et al. (21) in a randomized clinical trial on 51 children compared the antipyretic effects of two doses of $35 \mathrm{mg} / \mathrm{kg}$ and $15 \mathrm{mg} / \mathrm{kg}$ of rectal acetaminophen and an oral dose of $15 \mathrm{mg} / \mathrm{kg}$. Results of this study revealed no significant difference in maximum antipyretic effects of the drug, needed time for $1^{\circ} \mathrm{C}$ reduction of body temperature and mean body temperature among the three groups of patients. Based on the results of this study, antipyretic effects of the standard dose of oral and rectal acetaminophen and the higher dose of rectal acetaminophen were the same. This finding was in contrary to our results; however, as there were relatively few patients in each of the three groups of this study, the results may have been influenced.

Study limitations: It is possible that the acetaminophen was not distributed equally in the suppository form. Therefore, dividing the suppository into two or four pieces may have not achieved the therapeutic dose of the drug. Furthermore, differences in demographic features of the patients who enrolled in our study, their different underlying diseases, receiving other treatments especially consumption of oral antibiotics prior to the study may be the other factors which have affected the results of the study.

Conclusion: From gathering all these data, it can be concluded that in febrile children, administration of 30 $\mathrm{mg} / \mathrm{kg}$ of rectal acetaminophen may be more effective than the standard dose in reducing fever after 3 hours of medication without any complication and therefore, this higher dose of rectal acetaminophen can be used to treat fever in children. However, it is necessary to explain the frequent high doses of acetaminophen $(>90$ $\mathrm{mg} / \mathrm{kg} /$ day as mentioned in the introduction) are not recommended because it increases the chances of associated complications. Therefore, we propose this high dose rectal acetaminophen as initial (loading) dose in the treatment of febrile children.

\section{Acknowledgements}

There is no acknowledgments.

\section{Authors' Contribution}

Study concept and design: Hashemian, and Momtazbakhsh. Analysis and interpretation of data: Hashemian, Momtazbakhsh, and atrkar Roshan. Drafting of the manuscript: Hashemian. Critical revision of the manuscript for important intellectual content: Hashemian, Momtazbakhsh, and atrkar Roshan. Statistical analysis: Hashem- 
ian, and atrkar Roshan.

\section{Financial Disclosure}

This study was done by the researchers' autonomous investment.

\section{Funding/Support}

Non declared.

\section{References}

1. Nield LS, Kamat D. Fever. In: Kliegman RM, Stanton BF, Schor NF, et al , editor(s). Nelson Textbook of Pediatrics.19th ed. Philadelphia: WB Saunders; 2011

2. Treluyer JM, Tonnelier S, d'Athis P, Leclerc B, Jolivet-Landreau I, Pons G. Antipyretic efficacy of an initial 30-mg/kg loading dose of acetaminophen versus a $15-\mathrm{mg} / \mathrm{kg}$ maintenance dose. Pediatrics. 2001;108(4):E73.

3. Ward MA, Parcells CL. Fever Pathogenesis and treatment. In: Feigin RD, Cherry J, Demmler GJ, Kaplan SL, editor(s). Textbook of Pediatrics Infectious Disease. 6th ed. Philadelphia:Saunders; 2009. p.105-10.

4. Amdekar YK. Rational use of antipyretics. Indian Pediatr 2003;40(6):541-4.

5. Auria JP. Fever. In: Fox J, editor(s). Primary Health Care of Infants, Children \& Adolescents. 2nd ed. New York: Mosby; 2002. p. 704-5.

6. Russell FM, Shann F, Curtis N, Mulholland K. Evidence on the use of paracetamol in febrile children. Bull World Health Organ. 2003;81(5):367-72.

7. Scolnik D, Kozer E, Jacobson S, Diamond S, Young NL. Comparison of oral versus normal and high-dose rectal acetaminophen in the treatment of febrile children. Pediatrics. 2002;110(3):553-6.

8. Brown RD, Wilson JT, Kearns GL, Eichler VF, Johnson VA, Bertrand KM. Single-dose pharmacokinetics of ibuprofen and acetaminophen in febrile children. J Clin Pharmacol.1992;32(3):231-41.

9. Roberts LJ, Morrow JM. Analgesic-Antipyretic and anti-inflammatory agents. In: Goodman LS, Gilman A, editor(s). Goodman \& Gilman's the pharmacological basis of therapeutics. New York: McGraw-Hill; 2002. p. 703-4.

10. Birmingham PK, Tobin MJ, Henthorn TK, Fisher DM, Berkelhamer MC, Smith FA, et al. Twenty-four-hour pharmacokinetics of rectal acetaminophen in children: an old drug with new recommendations. Anesthesiology. 1997;87(2):244-52.

11. Hahn TW, Henneberg SW, Holm-Knudsen RJ, Eriksen K, Rasmussen SN, Rasmussen M. Pharmacokinetics of rectal paracetamo after repeated dosing in children. Br J Anaesth. 2000;85(4):512-9.

12. van der Marel CD, van Lingen RA, Pluim MA, Scoones G, van Dijk $\mathrm{M}$, Vaandrager JM, et al. Analgesic efficacy of rectal versus oral acetaminophen in children after major craniofacial surgery. Clin Pharmacol Ther. 2001;70(1):82-90.

13. Birmingham PK, Tobin MJ, Fisher DM, Henthorn TK, Hall SC, Cote CJ. Initial and subsequent dosing of rectal acetaminophen in children: a 24-hour pharmacokinetic study of new dose recommendations. Anesthesiology. 2001;94(3):385-9.

14. Montgomery CJ, McCormack JP, Reichert CC, Marsland CP. Plas ma concentrations after high-dose (45 mg.kg-1) rectal acetaminophen in children. Can J Anaesth. 1995;42(11):982-6.

15. Lee CKK, Tschudy MM, Arcara K. Drug doses. In: Tschudy MM, Arcara KM, editor(s). The Harriet Lane Handbook. 19th ed ed. Philadelphia: Mosby (Elsevier); 2012. p. 682-3.

16. Sweetman SC. Martindale. 36th ed. London: Pharmaceutical Press; 2009. p. 108-11.

17. Howell TK, Patel D. Plasma paracetamol concentrations after different doses of rectal paracetamol in older children A comparison of $1 \mathrm{~g}$ vs. $40 \mathrm{mg} \mathrm{x} \mathrm{kg(-1).} \mathrm{Anaesthesia.} \mathrm{2003;58(1):69-73.}$

18. Beck DH, Schenk MR, Hagemann K, Doepfmer UR, Kox WJ. The pharmacokinetics and analgesic efficacy of larger dose rectal acetaminophen $(40 \mathrm{mg} / \mathrm{kg})$ in adults: a double-blinded, randomized study. Anesth Analg. 2000;90(2):431-6

19. Treluyer JM, Tonnelier S, d'Athis P, Leclerc B, Jolivet-Landreau I, Pons G. Antipyretic efficacy of an initial 30-mg/kg loading dose of acetaminophen versus a $15-\mathrm{mg} / \mathrm{kg}$ maintenance dose. Pediatrics. 2001;108(4):E73.

20. Golestan M, Karbasi SA, Bafghi MS, et al . Comparsion of oral acetaminophen with different doses in febrile children. Iran J Pediatr 2005;15(4):373-8.

21. Blaisdell J, Mohrenweiser H, Jackson J, Ferguson S, Coulter S, Chanas B, et al. Identification and functional characterization of new potentially defective alleles of human CYP2C19. Pharmacogenetics. 2002;12(9):703-11

22. Nabulsi M, Tamim H, Sabra R, Mahfoud Z, Malaeb S, Fakih H, et al. Equal antipyretic effectiveness of oral and rectal acetaminophen: a randomized controlled trial [ISRCTN11886401]. BMC Pediatr. 2005;5:35. 